\title{
Analysis of Mental and Physical Fatigue Risk Factors in Utility Unit of Petrochemical Company
}

\author{
Analisis Faktor Risiko Kelelahan Kerja Fisik dan Mental di Unit Utility pada \\ Industri Bidang Petrokimia
}

\author{
Bian Shabri Putri Irwanto \\ Suara Surabaya \\ Jalan Wonokitri Besar No. 40 C Surabaya, East Java, 60256 Indonesia
}

\begin{abstract}
Introduction: Work exhaustion defined as a tired feeling felt by workers with different symptoms in each individual. In this study work fatigue was divided into two types, namely physical work fatigue and mental work fatigue. This study aims to determine risk factors of physical and mental fatigue on utility unit PT. Trans Pacific Petrochemical Indotama (TPPI) which produces petroleum or gas, as well as the chemical BTX. Methods: This research was an observational study with a cross-sectional method. Based on the problem characteristic and data analysis, this study belongs to analytical research. Data were collected by interview, questionnaires, measurement, and observations. The population is 36 workers and the sample size of this study is 33 respondents from utility unit workers. The sampling technique used simple random sampling. The variables in this study were age, years of service, work duration, workload, heat stress index, responsibility, and support from company's head. Results: Showed that factors associated with physical and mental fatigue are the age, workloads, work duration, and heat stress index. Conclusion: Physical fatigue and mental fatigue had correlation with age, workloads, work time, and heat stress index. The higher age, workload, work duration, and heat stress index, it will increasingly cause physical and mental fatigue faster and harder.
\end{abstract}

Keywords: fatigue risk factors, mental fatigue work, physical fatigue work

\section{ABSTRAK}

Pendahuluan: Kelelahan kerja merupakan perasaan keluhan lelah yang dirasakan oleh pekerja dengan perasaan berbeda pada setiap individunya. Pada penelitian ini kelelahan kerja dibagi menjadi dua jenis yaitu kelelahan fisik dan kelelahan mental. Tujuan penelitian ini adalah menganalisis faktor risiko kelelahan kerja fisik dan mental pada unit utility PT. Trans Pacific Petrochemical Indotama (TPPI) yang memperoduksi petroleum atau migas, serta bahan kimia BTX. Metode: Penelitian ini merupakan penelitian observasional dengan rancangan cross sectional. Berdasarkan karakteristik masalah dan analisis data, penelitian ini termasuk penelitian analitik. Pengumpulan data dilakukan dengan wawancara, membagikan kuesioner, pengukuran, dan observasi. Jumlah populasi adalah 36 pekerja dan besar sampel berjumlah 33 responden pekerja unit utility. Teknik pengambilan sampel menggunakan simple random sampling. Variabel pada penelitian ini adalah usia, masa kerja, lama waktu kerja, beban kerja, iklim kerja, tanggung jawab, dan dukungan pimpinan. Hasil: Penelitian menunjukkan bahwa faktor yang berhubungan dengan kelelahan kerja fisik dan mental adalah usia, beban kerja, lama waktu kerja, dan iklim kerja. Simpulan: Penelitian ini yang berhubungan dengan kelelahan kerja fisik dan kelelahan kerja mental yaitu usia, beban kerja, lama waktu kerja, dan iklim kerja. Semakin tinggi usia, beban kerja, lama waktu kerja, dan iklim kerja, maka akan semakin menimbulkan kelelahan kerja fisik dan mental semakin cepat dan berat.

Kata kunci: faktor risiko kelelahan, kelelahan kerja fisik, kelelahan kerja mental

\author{
Author for Correspondence: \\ Bian Shabri Putri Irwanto \\ Email: bianshabri1234@gmail.com \\ Telephone: +6281805008765
}

(C)2020 IJOSH. Open access under CC BY NC-SA license doi: 10.20473/ijosh.v9i1.2020.21-29 Received February 24, 2019, received in revised form April 14, 2020, Accepted April 27, 2020, Published: April 2020 


\section{INTRODUCTION}

The rapid technology development and the increasing usage of machinery in labor works are increasing in Indonesia to order to prepare for the industrialization era. However, in carrying out labor works, human will always remain the most important component. Every work carries inherent risk in the form of fatigue and accident in the workplace. Therefore, in work completion, health and safety should be the utmost importance. This is in accordance with Undang Undang Republik Indonesia Nomor 13 Tahun 2003 (2003) concerning labor work. Article 86 stated that workers are entitled to protection of occupational safety and health, morals, and morality and treatment in accordance with human dignity and religious values.

Based on the Data and Information Center of Indonesia Health Ministry, the highest number of work accident cases in 2011-2014 occurred in 2013, namely 35,917 cases (Kementerian Kesehatan RI, 2017). In addition, according to the International Labor Organization (ILO), every year there are more than 250 million accidents in the workplace and more than 160 million workers that suffer from hazard in the workplace. One of the causes that contribute to the high accident rate is fatigue, which gives a contribution rate of $50 \%$ to the occurrence of workplace accidents (Samahati et al., 2017) One of occupational health and safety problems that can trigger work accidents is fatigue. Fatigue refers to different physical and mental states, and all of them causes a decrease in work attention and endurance (Suma'mur, 2009). Fatigue can affect productivity, reduce performance and increase human error. Furthermore, it can also reduce efficiency and endurance during work.

Work-related fatigue can be caused by several factors, both internal and external. According to Suma'mur (2009) as for the factors that influence fatigue are worker characteristics, occupationrelated problems, work environment, and workers' physiological condition. Worker's characteristics may consist of age, gender, length of employment, nutritional status, education level, duration of rest, health status, marital status, distance of residence, and sleep duration. Factors that affect work may consist of workload, work time length, work shift, work attitude, and monotonous conditions. Factors that affect working environment may consist of heat stress index, noise, vibration, and lighting. Furthermore, there are psychological factors which consist of work stress, work structure, responsibility, and support from the heads of the company

Based on the description above, the researcher is interested in researching the workforce in utility unit of PT. Trans Pacific Petrochemical Indotama, which is a company engaged in the petrochemical and energy industry. The difference in research in PT. Trans Pacific Petrochemical Indotama with other research because workers must work for 24 hours as a supporter of other units such as generating power plants, producing steam generators, providing clean water as a support for the production process. In addition, workers also have a working time of $>8$ hours a day if there is a problem with the company. As well as workers who feel tired, the majority are workers who have high responsibility. So, it will cause physical work fatigue and mental work fatigue quickly for workers. From the initial data collected through the site survey, it was found that the number of workers employed in the utility unit was 36 people. The purpose of this study is to analyze the factors associated with physical and mental work fatigue of PT. Trans Pacific Petrochemical Indotama utility unit workers. The workers especially in this particular unit, have heavier responsibility than the other due to the fact that they produce utilities, or in other words, the support system of aromatic and platforming units, which means that this unit must operate 24 hours so the production process can keep continuing.

\section{METHODS}

Based on the data retrieval method, this research is included in observational research because research studies are carried out without any intervention or special treatment on the subject of research. The research is done by cross-sectional method, which is collecting data at a time or in onesitting observation. Whereas based on the nature of the problem and data analysis, this study is included in analytical research because it aims to determine the factors associated with the occurrence of work fatigue in the utility unit conducted on January 2019

Population in this research is all workers in PT. Trans Pacific Petrochemical .Indotama utility unit, which consists of 36 workers. While the sample is taken by simple random sampling method that results in 33 workers of workers in the unit mentioned above. 
Tools used in this research are interview guidelines, questionnaire that consist of factors that affect individual's characteristics, heat stress meter quest temp 36 that is used for measuring the work climate on the work environment, reaction timer that is used for measuring physical fatigue, Industrial Fatigue Research Committee (IFRC) questionnaire that is used for measuring mental fatigue, responsibility questionnaire, head support questionnaire, stopwatch, and office stationaries.

Data analysis consisted of univariate analysis to describe each variable and bivariate analysis using a chi-square test with a significant value of $95 \%$ or $\alpha=0.05$ to observe the relationship between the independent variables and the dependent variable. After that, the processed data will be presented in the form of tables and narrative texts to make it clearer.

\section{RESULT}

There are risks in the utility unit, namely physical work fatigue and mental work fatigue. This is because utility unit has tasks related to other units, such as providing electricity, processing sea water to polish water, processing liquid waste, and so on. The risk factors that can cause work fatigue are age, years of service, work duration, workload, heat stress index, responsibility, and support from company's head.

Based on table 1 shows that the level of work fatigue experienced by PT. Trans Pacific Petrochemical Indotama (TPPI) is quite varied. Table 1 shows that as many as 18 people $(54.5 \%)$ of the workforce experienced medium mental fatigue. Whereas the physical fatigue is experienced evenly for workers, as many as 11 people $(33.3 \%)$.

Table 1. Distribution of Physical and Mental Work Fatigue of Utility Unit Workers in PT. Trans Pacific Petrochemical Indotama (TPPI), January 2019

\begin{tabular}{ccc}
\hline Work Fatigue & \multicolumn{2}{c}{ Total Respondents } \\
\cline { 2 - 3 } & Frequency (n) & Percentage (\%) \\
\hline Physical Fatigue & & \\
Light & 11 & 33.3 \\
Moderate & 11 & 33.3 \\
Heavy & 11 & 33.3 \\
\hline Mental Fatigue & & \\
Moderate & 18 & 54.5 \\
Heavy & 15 & 45.5 \\
\hline
\end{tabular}

Table 2. Distribution of Age of Utility Unit Workers in PT. Trans Pacific Petrochemical Indotama (TPPI), January 2019

\begin{tabular}{ccc}
\hline \multirow{2}{*}{ Age } & \multicolumn{2}{c}{ Total Respondents } \\
\cline { 2 - 3 } & Frequency (n) & Percentage (\%) \\
\hline$\leq 35$ years old & 15 & 45.5 \\
$36-50$ years old & 18 & 54.5 \\
\hline Total & 33 & 100.0 \\
\hline
\end{tabular}

Table 3. Distribution of Years of Service of Utility Unit Workers in PT. Trans Pacific Petrochemical Indotama (TPPI), January 2019

\begin{tabular}{ccc}
\hline \multirow{2}{*}{ Years of Service } & \multicolumn{2}{c}{ Total Respondents } \\
\cline { 2 - 3 } & Frequency (n) & Percentage (\%) \\
\hline$\leq 3$ years & 16 & 48.5 \\
$>3$ years & 17 & 51.5 \\
\hline Total & 33 & 100.0 \\
\hline
\end{tabular}

Table 4. Distribution of Workload of Utility Unit Workers in PT. Trans Pacific Petrochemical Indotama (TPPI), January 2019

\begin{tabular}{ccc}
\hline \multirow{2}{*}{ Workload } & \multicolumn{2}{c}{ Total Respondents } \\
\cline { 2 - 3 } & Frequency (n) & Percentage (\%) \\
\hline Light & 15 & 45.5 \\
Moderate & 18 & 54.5 \\
\hline Total & 33 & 100.0 \\
\hline
\end{tabular}

Based on table 2, out of the total respondents of 33 people, mostly are aged $36-50$ years is 18 respondents $(54.5 \%)$, while the category of $\leq 35$ years is 15 respondents $(45.5 \%)$.

Years of service divided into $\leq 3$ years and $>3$ years. Based on table 3 , out of the total respondents of 33 people, mostly are years of service $>3$ years is 17 respondents $(51.5 \%)$, while the category of $\leq$ 3 years is 16 respondents $(48.5 \%)$.

Workload divided into light and moderate. Based on table 4, out of the total respondents of 33 people, mostly are moderate is 18 respondents $(54.5 \%)$, while the category of light is 15 respondents $(45.5 \%)$.

Work duration divided into $\leq 8$ hours per day and $>8$ hours per day. Based on table 5 , out of the total respondents of 33 people, mostly are $>$ 8 hours per day is 18 respondents $(54.5 \%)$, while the category of $\leq 8$ hours per day is 15 respondents $(45.5 \%)$. 
Table 5. Distribution of Work duration of Utility Unit Workers in PT. Trans Pacific Petrochemical Indotama (TPPI), January 2019

\begin{tabular}{ccc}
\hline \multirow{2}{*}{ Work Duration } & \multicolumn{2}{c}{ Total Respondents } \\
\cline { 2 - 3 } & Frequency (n) & Percentage (\%) \\
\hline$\leq 8$ hours per day & 15 & 45.5 \\
$>8$ hours per day & 18 & 54.5 \\
\hline Total & 33 & 100.0 \\
\hline
\end{tabular}

Table 6. Distribution of Heat Stress Index of Utility Unit Workers in PT. Trans Pacific Petrochemical Indotama (TPPI), January 2019

\begin{tabular}{ccc}
\hline \multirow{2}{*}{ Heat Stress Index } & \multicolumn{2}{c}{ Total Respondents } \\
\cline { 2 - 3 } & Frequency (n) & Percentage (\%) \\
\hline$\leq$ TLV & 15 & 45.5 \\
$>$ TLV & 18 & 54.5 \\
\hline Total & 33 & 100.0 \\
\hline
\end{tabular}

Heat stress index divided into $\leq$ TLV and $>$ TLV. Based on table 6 , out of the total respondents of 33 people, mostly are $>$ Threshold Limit Value (TLV) is 18 respondents $(54.5 \%)$, while the category of $\leq$ Threshold Limit Value (TLV) is 15 respondents (45.5\%).

Responsibility divided into moderate and heavy. Based on table 7, out of the total respondents of 33 people, mostly are heavy is 18 respondents $(54.5 \%)$, while the category moderate is 15 respondents $(45.5 \%)$.

Support from company's head divided into moderate and heavy. Based on table 8 , out of the total respondents of 33 people, mostly are heavy is 17 respondents $(51.5 \%)$, while the category moderate is 16 respondents $(48.5 \%)$.

Table 9 shows the results of the chi-square analysis that there is a relationship between age, years of service, work duration, workload, heat stress index, and physical work fatigue of utility unit workers in PT. Trans Pacific Petrochemical Indotama. While responsibility and support from company's head do not have any relationship with the physical work fatigue.

Table 10 shows the results of chi-square analysis that there is a relationship between working age, workload, heat stress index, responsibility and work safety of utility unit workers of PT. Trans
Table 7. Distribution of Responsibility of Utility Unit Workers in PT. Trans Pacific Petrochemical Indotama (TPPI), January 2019

\begin{tabular}{ccc}
\hline \multirow{2}{*}{ Responsibility } & \multicolumn{2}{c}{ Total Respondents } \\
\cline { 2 - 3 } & Frequency (n) & Percentage (\%) \\
\hline Moderate & 15 & 45.5 \\
Heavy & 18 & 54.5 \\
\hline Total & 33 & 100.0 \\
\hline
\end{tabular}

Table 8. Distribution of Support from Company's Head of Utility Unit Workers in Trans Pacific Petrochemical Indotama (TPPI), January 2019

\begin{tabular}{ccc}
\hline S u p p or t & f r o m \\
Company's Head & Trequency (n) & Percentage (\%) \\
\cline { 2 - 3 } Moderate & 16 & 48.5 \\
Heavy & 17 & 51.5 \\
\hline Total & 33 & 100.0 \\
\hline
\end{tabular}

Pacific Petrochemical Indotama. Whereas there is no relationship between years of service, company's head support and mental fatigue.

\section{DISCUSSION}

\section{Work Fatigue}

Fatigue felt by workers does not occur only when the work ends or at the end of the shift, but they also occur during working time, even before work started. (Suma'mur, 2009). Work-related exhaustion describes the entire body's response to activities carried out and exposure received during work. The body will be prone to fatigue when doing work for 8 hours. There are three indications of work Fatigue, namely weakening in activity, weakening motivation, and physical fatigue. Workers that suffer from work fatigue will experience symptoms such as diziness, tiredness in overall body, heavy feeling in legs, yawning, chaotic mind, drowsiness, and decreasing concentration.

The cause of physical and mental fatigue on the utility unit workers of PT. Trans Pacific Petrochemical Indotama may comes from the responsibility of being the basic and vital foundation of other units. The utility units is in charge of electricity production, polish water conversion, sea 
Table 9. Correlation between Age, Years of Service, Work Duration, Workload, Heat Stress Index, Responsibility, Support from the Head of Company, and Physical Work Fatigue of Utility Unit Workers in Trans Pacific Petrochemical Indotama (TPPI), January 2019

\begin{tabular}{|c|c|c|c|c|c|c|c|c|c|c|}
\hline \multirow{3}{*}{ Variable } & \multicolumn{6}{|c|}{ Physical Work Fatigue } & \multirow{2}{*}{\multicolumn{2}{|c|}{ Total }} & \multirow{3}{*}{$\begin{array}{c}\rho \\
\text { Value }\end{array}$} & \multirow{3}{*}{$\begin{array}{c}\text { Contingency } \\
\text { Coefficient }\end{array}$} \\
\hline & \multicolumn{2}{|c|}{ Light } & \multicolumn{2}{|c|}{ Moderate } & \multicolumn{2}{|c|}{ Heavy } & & & & \\
\hline & $\mathbf{n}$ & $\%$ & n & $\%$ & $\mathrm{n}$ & $\%$ & $\mathbf{N}$ & $\%$ & & \\
\hline \multicolumn{11}{|l|}{ Age } \\
\hline$\leq 35$ years old & 1 & 6.7 & 10 & 66.7 & 4 & 26.6 & 15 & 100 & \multirow{2}{*}{0.000} & \multirow{2}{*}{0.564} \\
\hline $36-50$ years old & 10 & 55.6 & 1 & 5.6 & 7 & 38.8 & 18 & 100 & & \\
\hline \multicolumn{11}{|l|}{ Years of Service } \\
\hline$\leq 3$ years & 10 & 62.4 & 1 & 6.3 & 5 & 31.3 & 16 & 100 & \multirow{2}{*}{0.001} & \multirow{2}{*}{0.556} \\
\hline$>3$ years & 1 & 5.8 & 10 & 58.8 & 6 & 35.2 & 17 & 100 & & \\
\hline \multicolumn{11}{|l|}{ Work Duration } \\
\hline$\leq 8$ hours per day & 10 & 58.8 & 6 & 35.3 & 1 & 5.9 & 17 & 100 & \multirow{2}{*}{0.009} & \multirow{2}{*}{0.473} \\
\hline$>8$ hours per day & 1 & 6.3 & 5 & 31.3 & 10 & 62.4 & 16 & 100 & & \\
\hline \multicolumn{11}{|l|}{ Workload } \\
\hline Light & 9 & 60.0 & 5 & 33,3 & 1 & 6.7 & 15 & 100 & \multirow{2}{*}{0.003} & \multirow{2}{*}{0.512} \\
\hline Moderate & 2 & 11.1 & 6 & 33.3 & 10 & 55.6 & 18 & 100 & & \\
\hline \multicolumn{11}{|l|}{ Heat Stress Index } \\
\hline$\leq \mathrm{TLV}$ & 9 & 60.0 & 5 & 33.3 & 1 & 6.7 & 15 & 100 & \multirow{2}{*}{0.003} & \multirow{2}{*}{0,512} \\
\hline$>\mathrm{TLV}$ & 2 & 11.1 & 6 & 33.3 & 10 & 55.6 & 18 & 100 & & \\
\hline \multicolumn{11}{|l|}{ Responsibility } \\
\hline Moderate & 6 & 40.0 & 6 & 40.0 & 3 & 20.0 & 15 & 100 & \multirow{2}{*}{0.333} & \multirow{2}{*}{0.250} \\
\hline Heavy & 5 & 27.8 & 5 & 27.8 & 8 & 44.4 & 18 & 100 & & \\
\hline \multicolumn{11}{|l|}{$\begin{array}{c}\text { Support from } \\
\text { Company's Head }\end{array}$} \\
\hline Moderate & 5 & 31.3 & 5 & 31.3 & 6 & 37.4 & 16 & 100 & \multirow{2}{*}{0.886} & \multirow{2}{*}{0.085} \\
\hline Heavy & 6 & 35.3 & 6 & 35.3 & 5 & 29.4 & 17 & 100 & & \\
\hline
\end{tabular}

water extraction to be used as company's water cooling component, and wastewater treatment. Workers must be available for 24 hours otherwise the other unit will be hindered. In addition the fatigue also affected by age, years of service, workload, work duration, heat stress index, responsibilities, and support from company's head.

\section{The Correlation between Age and Work Fatigue on Utility Unit Workers of PT. Trans Pacific Petrochemical Indotama}

One of individual characteristics that can be considered as factors affecting work-related fatigue is age. Age will affect one's ability, condition and body capacity when doing daily activities. According to Setyawati (2010) age can affect one's physical condition. The older workers may feel their physical strength improving, followed by their mental maturity and experience. Research conducted by Setyawati (2010) determines that age is the second highest variable that can affect workrelated fatigue.

Based on chi-square statistical tests results, the relationship between age and physical fatigue resulting in $\rho$ value $=0.000$, which means that there is a relationship between age and physical fatigue. This is proven by the majority of workers around 36-50 years old. Age has something to do workers' physical strength. As workers get older, their physical strength is decreasing, which resulting in physical fatigue. Whereas younger workers have more energy in doing physical work, so they can control their fatigue better than the older workers.

While the results of the study on the relationship of age with mental fatigue shows $p$ value $=0.007$, which means that there is a relationship between age and mental fatigue. This may be because as the workers get older, they are no longer suitable 
Table 10. Correlation between Age, Years of Service, Work Duration, Workload, Heat stress index, Responsibility, Support from Company's Head and Mental Work Fatigue of Utility Unit Workers in Trans Pacific Petrochemical Indotama (TPPI), January 2019

\begin{tabular}{|c|c|c|c|c|c|c|c|c|}
\hline \multirow{3}{*}{ Variable } & \multicolumn{4}{|c|}{ Mental Fatigue } & \multirow{2}{*}{\multicolumn{2}{|c|}{ Total }} & \multirow{3}{*}{$\begin{array}{c}\rho \\
\text { Value }\end{array}$} & \multirow{3}{*}{$\begin{array}{r}\text { Contingency } \\
\text { Coefficient }\end{array}$} \\
\hline & \multicolumn{2}{|c|}{ Moderate } & \multicolumn{2}{|c|}{ Heavy } & & & & \\
\hline & $\mathbf{n}$ & $\%$ & $\mathbf{n}$ & $\%$ & $\mathbf{N}$ & $\%$ & & \\
\hline \multicolumn{9}{|l|}{ Age } \\
\hline$\leq 35$ years old & 12 & 80.0 & 3 & 20.0 & 15 & 100 & \multirow{2}{*}{0.007} & \multirow{2}{*}{0.423} \\
\hline $36-50$ years old & 6 & 33.3 & 12 & 66.7 & 18 & 100 & & \\
\hline \multicolumn{9}{|l|}{ Years of Service } \\
\hline$\leq 3$ years & 10 & 62.5 & 6 & 37.5 & 16 & 100 & \multirow{2}{*}{0.373} & \multirow{2}{*}{0.153} \\
\hline$>3$ years & 8 & 47.1 & 9 & 52.9 & 17 & 100 & & \\
\hline \multicolumn{9}{|l|}{ Work Duration } \\
\hline$\leq 8$ hours per day & 12 & 80.0 & 3 & 20.0 & 15 & 100 & \multirow{2}{*}{0.007} & \multirow{2}{*}{0.423} \\
\hline$>8$ hours per day & 6 & 33.3 & 12 & 66.7 & 18 & 100 & & \\
\hline \multicolumn{9}{|l|}{ Workload } \\
\hline Light & 13 & 86.7 & 2 & 13.3 & 15 & 100 & \multirow{2}{*}{0.001} & \multirow{2}{*}{0.507} \\
\hline Moderate & 5 & 27.8 & 13 & 72.2 & 18 & 100 & & \\
\hline \multicolumn{9}{|l|}{ Heat Stress Index } \\
\hline$\leq \mathrm{NAB}$ & 13 & 86.7 & 2 & 13.3 & 15 & 100 & \multirow{2}{*}{0.001} & \multirow{2}{*}{0.507} \\
\hline$<$ NAB & 5 & 27.8 & 13 & 72.2 & 18 & 100 & & \\
\hline \multicolumn{9}{|l|}{ Responsibility } \\
\hline Moderate & 11 & 73.3 & 4 & 26.7 & 15 & 100 & \multirow{2}{*}{0.048} & \multirow{2}{*}{0.326} \\
\hline Heavy & 7 & 38.9 & 11 & 61.1 & 18 & 100 & & \\
\hline \multicolumn{9}{|c|}{ Support from Company's Head } \\
\hline Moderate & 11 & 68.8 & 5 & 31.2 & 16 & 100 & \multirow{2}{*}{0.112} & \multirow{2}{*}{0.267} \\
\hline Heavy & 7 & 41.2 & 10 & 58.8 & 17 & 100 & & \\
\hline
\end{tabular}

with works that carry heavy burden as they might be pressured to think more, that can lead to mental fatigue. This result is also supported by Atiqoh (2014) which stated that there is indeed a relationship between age and mental fatigue.

The Correlation between Years of Service and Work Fatigue on Utility Unit Workers of PT. Trans Pacific Petrochemical Indotama

Years of Service is the accumulation of time starting from the official enrollment until the time the research is conducted. According to Suma'mur (2009), he states that workers that have been in service for 10 years are able to socialize and adapt to their work and environment already. According to Setyawati (2010) the causes of work fatigue, workplace accidents, and losses occur because the workforce is less skilled, less passionate, less precise, and emotionally disturbed. These things are considered part of earning processes that develop further the longer they work. Workers that have been in service longer than the other tend to easily adjust to their work environment due to their rich experience, the ability to stabilize their emotion so they can work regularly, and optimally.

Based on the chi-square statistical test result, the $\rho$ value $=0.001$ was obtained, which means that there is a relationship between years of service and work fatigue. This is proven by the results of the relationship study between the tenure and physical work fatigue of the majority workers with year of service $>3$ years, so the workers have understood the right and ergonomic attitude in order for them to be able to endure more works.

While the results of the relationship study between years of service with mental fatigue shows $\rho$ value $=0.373$, so there is no relationship between years of service and mental fatigue. This is because no matter how long their years of service, it does not affect their mentality, due to the nonmonotonous work they do that can keep mental fatigue to minimum. This research is supported by 
research conducted by Fatmawaty, Alam and Suyuti (2016) which shows that there is no relationship between years of service and workers fatigue. Years of service is not a direct factor that can cause mental work fatigue, this is because utility unit workers do physical work in the same work environment, so they also face the same difficulty in the thinking process. Hence, none of the workers will feel under pressure, that may lead to mental fatigue.

\section{The Correlation between Work Duration and Work Fatigue on Utility Unit Workers of PT. Trans Pacific Petrochemical Indotama}

Work duration is the length of time the worker does the work within one day. Working time will certainly affect performance, productivity, and health. According to Suma'mur (2009) the most important aspect in terms of work duration, is the length of time the workforce can work well, the dynamic between work time and rest, and the time to work in one day according to time period. Generally, workers optimal working hours is 6 to 10 hours. If the duration is extended more than the workers can take, there will be no efficiency, effectiveness, and optimal work productivity, even the quality and results will decrease in addition to fatigue, health problems, illness, accidents and dissatisfaction.

Based on the chi-square statistical test result, the $\rho$ value $=0.009$ was obtained, which means that there is a relationship between work duration and physical fatigue. This is because during research process, the workers have some works that need to be done, hence the work duration is $>8$ hours a day. The longer the Work duration, the easier it is for workers to experience physical fatigue.

While the results of the relationship study between of work duration and mental fatigue shows $\rho$ value $=0.007$ which means that there is a relationship between the work duration and mental fatigue. This is because the longer the workes work, the workers are more prone to experience increased stress and impaired circadian rhythms, which leads to mental fatigue.

The results of this study is supported by research conducted by Hastuti (2015) which states that there is a relationship between work duration and work fatigue.

\section{The Correlation between Workload and Work Fatigue on Utility Unit Workers of PT. Trans Pacific Petrochemical Indotama}

Workload is a difference between ability or work capacity and the work demands that is faced by workers (Tarwaka, 2015). Workload experienced by utility unit workers of PT. Trans Pacific Petrochemical Indotama in general varied due to the difference in the work performed. Their work is divided based on work area. In this study, the majority of workers in the power generator unit felt moderate workload. This is because the unit is in charge of check patrolling, pouring chemicals, starting and stopping the pump in the area in which if the area is not working, it will disable the work of other unit. Whereas, the other workers received different workloads, such as polish water conversion (turning sea water to polish water) liquid waste treatment, and so on. Based on the chi-square statistical test results that shows $\rho$ value $=0.003$, it is proven that there is a relationship between workload and physical work fatigue.

In addition, the results of the relationship study between workload and mental fatigue that shows $\rho$ value $=0.001$ means that there is a relationship between workload and mental fatigue. Physical activities as well as accumulated workloads that is followed by workers inability to adjust can result in psychological problems, namely stress, for the workforce. Stress happened because the workforce is unable to adjust themselves to the workload.

The results of this study is supported by research conducted other study that also stated that there is a relationship between workload and work fatigue (Juliana, Camelia and Rahmiwati, 2018).

\section{The Correlation between Heat Stress Index and Work Fatigue on Utility Unit Workers of PT. Trans Pacific Petrochemical Indotama}

Heat stress index is a combination of air temperature, air movement speed, air humidity, and radiation heat. Those four factors, combined by heat originating from within the body is called heat stress (Suma'mur, 2009). Heat stress index can affect the performance, efficiency, effectiveness, and work productivity of the workforce. The heat stress index in a work environment should be neutral or not too low that can cause workers to be cold and also not too highy which can cause workers to get hot, thus creating maximum and optimal work results.

According to Suma'mur (2009) the comfortable temperature for Indonesian people is between 24-26 ${ }^{\circ} \mathrm{C}$. Heat stress index has important role in body's metabolic rate that produces heat. Workers who work in high-temperature work environments can harm their safety and health. Therefore, it is necessary to adjust work time and provide appropriate protection for workers. 
Based on the chi-square statistical test result, the $\rho$ value $=0.003$ means that there is a relationship between heat stress index and physical work fatigue. The relationship study between heat stress index and mental fatigue shows $\rho$ value $=0.001$ which means that there is also a relationship between heat stress index and Mental fatigue.

The majority of workers that suffer from heavy physical and mental fatigue comes from the power generator unit workers. This is due to the higher level of energy required, and followed by the highest heat stress index among other areas, even exceeding the threshold value.

The company has provided rest area, a room with temperature between $24-26^{\circ} \mathrm{C}$ that is apart from work area. But the drinking water outlet is not easily accessible yet. The company should pay more attention to this issue, as this can help workers to reduce their work fatigue.

\section{The Correlation between Responsibility and Work Fatigue on Utility Unit Workers of PT. Trans Pacific Petrochemical Indotama}

Responsibility is an act carried out by each individual based on the obligations they have. Workers who have higher mental workload and responsibility that are more prone to suffer from fatigue compared to workers with high physical workload (Tarwaka, 2015).

In this study, the results showed that $\rho$ value $=$ 0.333 , which means there is no relationship between responsibility and physical work fatigue. This result is supported by Suwardi and Amin (2010) that states that Responsibility has no significant effect on worker performance.

While the relationship between responsibility and mental fatigue received a $\rho$ value $=0.048$, which means that there is a relationship between responsibility and mental fatigue. This is because when worker has higher and more responsibility, then they will carry out their work more seriously compared to those who have low or moderate responsibility. This can lead to mental work fatigue.

\section{The Correlation between Support from Company's Head and Work Fatigue on Utility Unit Workers of PT. Trans Pacific Petrochemical Indotama}

Work-related exhaustion can occur in a workplace when there is no good relationship among workers or between workers and company's head. According to Tarwaka (2015) the signs of fatigue and stress due to work are suspicions among workers, lack of good communication and less comfort in doing work. The head of the company and the workers should work in harmony as it can create comfortable working climate.

The result of this study reveals that relationship between support from company's head and physical fatigue received $\rho$ value $=0.886$, which means that there is no relationship between support from company's head and physical fatigue.

While the result of the relationship study between support from company's head and mental fatigue received $\rho$ value $=0.112$, which means that there is also no relationship between support from company's head and mental fatigue.

The utility unit of PT. Trans Pacific Petrochemical Indotama (TPPI) has been implementing that every work done is controlled and directed by the head of the company. Communication built between leader and subordinates has been going well enough, including communication in problem solving. Furthermore, the head of the company always provide helpful inputs whenever their workers face some troubles, and always open for workers suggestions that can enhance their work.

This result is also supported by research conducted by Yuliana (2013) which states that there is no relationship between support from company's head with mental fatigue.

\section{CONCLUSION}

Based on the results of research that has been done in utility unit workers of PT. Trans Pacific Petrochemical Indotama, light, moderate, and heavy physical fatigue is equal at $(53.3 \%)$, Moderate mental work fatigue is as much as $(54.5 \%)$, workers aged $36-50$ years is as much as $(54.5 \%)$, workers with years of service $>3$ years is as much as $(51.5 \%)$, workers with work duration $>8$ hours is as much as (54.5\%), Moderate workload is as much as $(54.5 \%)$, heat stress index $>$ Threshold Limit Value (TLV) is as much as (54.5\%), workers with heavy responsibility is as much as (54.5\%), and workers who received high support from company's head is as much as $(51.5 \%)$. Based on the analytics result, there is no relationship between responsibility and support from company's head with physical work fatigue and there is no relationship between years of service and support from company's head 
with mental work fatigue on utility unit workerfect of PT. Trans Pacific Petrochemical Indotama. In addition, there is a relationship between age, years of service, workload, work duration and heat stress index with physical fatigue, furthermore, there is a relationship between age, workload, work duration, heat stress index, and responsibility with mental fatigue on utility unit workers of PT. Trans Pacific Petrochemical Indotama.

\section{ACKNOWLEDGEMENT}

I am grateful to all of those with whom $i$ have had the pleassure to work during this and other related research. This work would not have been possible without the support of PT. Trans Pacific Petrochemical Indotama. I also like to thank the Faculty of Public Health of Universitas Airlangga as our place of studying for giving me knowledge. Iam especially indebted to Dr. Indriati Paskarini, S.H., M.Kes, as my lecturer and mentor, who has been supportive of my study. She has taught me more than i could ever give her credit for here. She has shown me by his example, what a good person should be.

Nobody has been more important to me in the pursuit of this research than the members of my family. I would like to thank my parents, whose love and guidance are with me in whatever i pursue. Besides of that, $i$ wish to thank my loving sister and bestfriends who provide unending inspiration.

\section{REFERENCES}

Atiqoh, J. (2014) 'Faktor-Faktor yang Berhubungan dengan Kelelahan Kerja pada Pekerja Konveksi Bagian Penjahitan di CV. Aneka Garment Gunungpati Semarang', Jurnal Kesehatan Masyarakat (e-Journal), 2(2), pp. 119-126.
Fatmawaty, M., Alam, S. and Suyuti, A. A. (2016) 'Faktor yang Berhubungan dengan Kelelahan Kerja pada Perawat IGD di RSUD Haji Makassar Tahun 2014', Al-Sihah: Public Health Science Journal, 8(1), pp. 39-48.

Hastuti, D. D. (2015) Hubungan antara Lama Kerja dengan Kelelahan pada Pekerja Konstruksi di PT Nusa Raya Cipta Semarang. Undergraduate Thesis. Semarang: Faculty of Health Sciences, Universitas Negeri Semarang.

Juliana, M., Camelia, A. and Rahmiwati, A. (2018) 'Analisis Faktor Risiko Kelelahan Kerja pada Karyawan Bagian Produksi PT. Arwana Anugrah Keramik, Tbk', Jurnal Ilmu Kesehatan Masyarakat, 9(1), pp. 53-63.

Kementerian Kesehatan RI (2017) Data dan Informasi Profil Kesehatan Indonesia 2016, Kementerian Kesehatan RI.

Samahati, G. V. et al. (2017) 'Hubungan Antara Shift Kerja Dan Beban Kerja Dengan Kelelahan Kerja Pada Pekerja Area Terbatas Di PT. Pertamina Terminal Bahan Bakar Minyak (BBM) Kota Bitung', Scientific Article. Manado: Faculty of Publich Health Universitas Sam Ratulangi .

Setyawati (2010) Selintas Tentang Kelelahan Kerja. Yogyakarta: Amara Books.

Suma'mur, P. K. (2009) Higiene Perusahaan Kesehatan Kerja. Jakarta: Gunung Agung.

Tarwaka (2015) Ergonomi Industri, Dasar-dasar Pengetahuan dan Aplikasi di Tempat Kerja. 2nd edn. Surakarta: Harapan Press.

Undang Undang Republik Indonesia Nomor 13 Tahun 2003 (2003) Ketenagakerjaan. Jakarta.

Yuliana, E. (2013) Hubungan Shift Kerja, Karakteristik Individu, dan Faktor Psikologi dengan Kelelahan Kerja Subyektif (Studi Pada Pekerja Helper PT PJB UPHT Gresik). Undergraduate Thesis. Surabaya: Faculty of Public Health, Universitas Airlangga. 